\title{
Sore throat... don't forget Lemierre's syndrome
}

\author{
Niall D Crowley, ${ }^{1}$ Avelino C Verceles, ${ }^{2}$ Robert M Reed ${ }^{2}$
}

${ }^{1}$ School of Medicine, University of Maryland, Baltimore, Maryland, USA

${ }^{2}$ Division of Pulmonary and Critical Care Medicine, University of Maryland, Baltimore, Maryland, USA

\section{Correspondence to} Dr Robert M Reed, rreed@medicine.umaryland.edu

Accepted 25 December 2014

\section{DESCRIPTION}

A young man in his 20s presented to the emergency department reporting of a sore throat, fever, chills and cough beginning 3 days prior. On the basis of a negative rapid streptococcal antigen test, he was discharged with supportive care for a presumed viral upper respiratory infection. He returned 2 days later with fever, cough productive of yellow sputum, shortness of breath and right-sided pleuritic chest pain. He quickly developed respiratory distress requiring intubation. A CT of the chest (figure 1 and video 1) demonstrated a right pleural effusion that was later confirmed to be an empyema, and scattered nodular infiltrates consistent with septic emboli. Lemierre's syndrome most often occurs in adolescents and young adults following an oropharyngeal infection not treated by antibiotics or treated with antibiotics that do not cover Fusobacteria and should be suspected with new or worsening symptoms several days after initial presentation. ${ }^{1}{ }^{2}$ Oral anaerobes, classically Fusobacteria necrophorum, spread to adjacent tissues causing septic thrombophlebitis of the internal jugular vein. ${ }^{2}$ Symptoms of fever, chills, respiratory distress, neck pain and swelling usually occur within a week of the initial infection and are due to septic thrombi and emboli. ${ }^{2}$ Physical examination often reveals tenderness or swelling on the side of the affected vein, and typical laboratory findings include leucocytosis, thrombocytopenia and bacteraemia. Diagnosis is performed through blood cultures and imaging demonstrating thrombosis of the internal jugular vein. Treatment consists of antibiotic therapy directed at the offending organism, and in select circumstances surgical exploration of the internal jugular vein or anticoagulation. $^{13}$

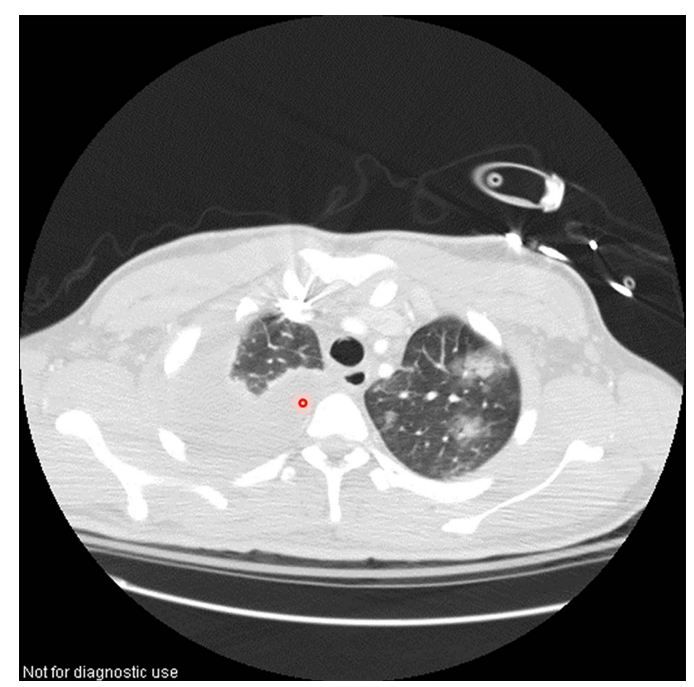

Video 1 CT review of anatomy.

\section{Learning points}

- In a patient presenting with sore throat, pain or a mass palpable in the neck should raise the suspicion for Lemierre's syndrome. ${ }^{2}$

- The incidence of Lemierre's may be increasing due to less antibiotic use for non-streptococcal pharyngitis. ${ }^{2}$

- Although often cited as the first to describe this syndrome, André Lemierre gave credit in his original paper to the German physician Schottmüller for describing this entity in 1918, and it had been described even earlier by Courmont and Cade in 1900.
To cite: Crowley ND Verceles AC, Reed RM. BMJ Case Rep Published online: [please include Day Month Year] doi:10.1136/bcr-2014208225

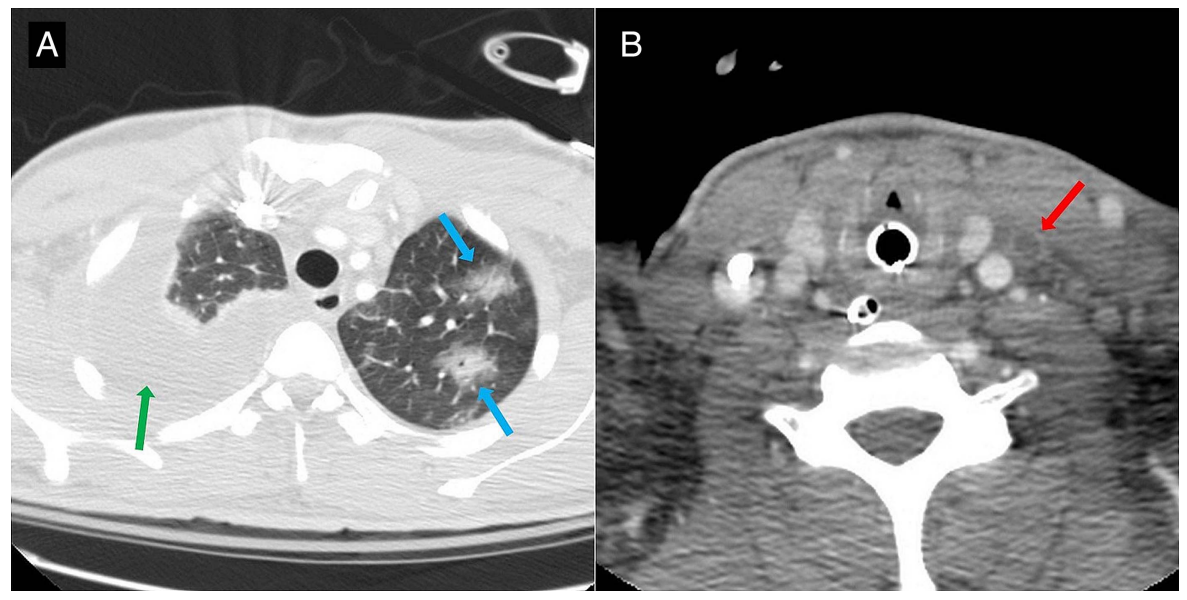

Figure 1 (A) CT of the chest demonstrating empyema (green arrow), and nodular infiltrates (blue arrows) typical of septic emboli. (B) CT of the neck showing thrombosis of the left internal jugular vein (red arrow). 
Contributors All authors contributed to the research and writing of this manuscript, and all authors saw and approved the final manuscript.

Competing interests None.

\section{Patient consent None.}

Provenance and peer review Not commissioned; externally peer reviewed.

\section{REFERENCES}

1 Golpe R, Marin B, Alonso M. Lemierre's syndrome (necrobacillosis). Postgrad Med J 1999;75:141-4.

2 Karkos PD, Asrani S, Karkos CD, et al. Lemierre's syndrome: a systematic review. Laryngoscope 2009;119:1552-9.

3 Phua CK, Chadachan VM, Acharya R. Lemierre syndrome-should we anticoagulate? A case report and review of the literature. Int J Angiol 2013;22:137-42.

Copyright 2015 BMJ Publishing Group. All rights reserved. For permission to reuse any of this content visit http://group.bmj.com/group/rights-licensing/permissions.

BMJ Case Report Fellows may re-use this article for personal use and teaching without any further permission.

Become a Fellow of BMJ Case Reports today and you can:

- Submit as many cases as you like

- Enjoy fast sympathetic peer review and rapid publication of accepted articles

- Access all the published articles

- Re-use any of the published material for personal use and teaching without further permission

For information on Institutional Fellowships contact consortiasales@bmjgroup.com

Visit casereports.bmj.com for more articles like this and to become a Fellow 